\title{
Model Penyelesaian Konflik Kewenangan dalam Hal Timbulnya Dampak Dumping Limbah Batu Bara: Studi Kasus pada Pemerintah Kota Bengkulu dengan Pemerintah Kabupaten Bengkulu Tengah
}

\author{
J.T. Pareke ${ }^{18}$ dan David Aprizon Putra ${ }^{19}$
}

\begin{abstract}
Abstrak
Penelitian ini difokuskan pada model penyelesaian konflik kewenangan terhadap timbulnya dampak dumping limbah batu bara studi kasus pada Pemerintah Kota (Pemkot) Bengkulu dengan Pemerintah Kabupaten (Pemkab) Bengkulu Tengah: pertama, bagaimana dampak kerusakan yang terjadi akibat dari pencemaran di daerah hilir aliran Sungai Bengkulu; kedua, bagaimana tindakan pencegahan yang dilakukan terhadap perluasan dampak pencemaran bagi perusahaan di daerah hulu sungai Bengkulu; dan ketiga, bagaimana konsep ideal pencegahan perluasan dampak pencemaran yang seharusnya dilakukan oleh Pemerintah Provinsi Bengkulu. Penelitian ini menggunakan pendekatan normatif-sosiologis, menggunakan data hasil studi lapangan, dan melakukan studi kepustakaan. Studi ini menyimpulkan bahwa: pertama, ada beberapa dampak yang diakibatkan dari pencemaran limbah batu bara, diantaranya dampak terhadap kerusakan ekosistem sungai, dampak terhadap kondisi air (PDAM Kota Bengkulu), efek domino yang terjadi di hilir sungai, dan dampak terhadap estetika lingkungan; kedua, tindakan pencegahan yang dilakukan terhadap perluasan dampak pencemaran bagi perusahaan di daerah hulu Sungai Bengkulu masih terbatas pada instrumen perizinan saja, tidak menitikberatkan pada pengawasan yang lebih ketat; ketiga, konsep ideal pencegahan perluasan dampak pencemaran yang seharusnya dilakukan adalah dengan melibatkan berbagai pihak terkait, seperti pemerintah, masyarakat, dan stakeholder yang dimotori oleh pemerintah provinsi karena konflik kewenangan ini menyangkut dua wilayah administratif yang berbeda.
\end{abstract}

Kata Kunci: konflik kewenangan, dampak dumping, pencemaran lingkungan, kerusakan ekosistem sungai, limbah batu bara.

\section{Conflict of Authority Resolution Model in Case of Emergence of Coal Dumping Effect: Case Study on Bengkulu Municipality Government and Bengkulu Regency Government}

\begin{abstract}
This study focuses on authority conflict resolution model concerning the impact of coal waste dumping-case study on the Bengkulu Municipality Government and Bengkulu Regency

18 Dosen Fakultas Hukum Universitas Muhammadiyah Bengkulu, JI. Salak Raya Kampus II UMB Lingkar Timur Bengkulu, themirrorofmysoul@gmail.com, S.H. (Universitas Bengkulu), M.H. (Universitas Bengkulu).

19 Mahasiswa Magister Ilmu Hukum Universitas Padjadjaran Bandung, Jl. Dipati Ukur No. 35 Bandung, davidaprizonputra@ymail.com, S.H. (Universitas Muhammadiyah Bengkulu).
\end{abstract}


J.T. Pareke dan David Aprizon Putra: Model Penyelesaian Konflik Kewenangan dalam Hal Timbulnya Dampak Dumping Limbah Batu Bara: Studi Kasus pada Pemerintah Kota Bengkulu dengan Pemerintah Kabupaten Bengkulu Tengah

Government: first, what is the damage caused by pollution in the river downstream of Bengkulu; second, what are the precautions against the impact of the expansion of the company's pollution in the headwaters area of Bengkulu; and third, what is the ideal concept of prevention of the expansion of pollution impact that should have been conducted by the Government of Bengkulu Province. This research utilizes sociological-normative approach, using data from field and literature. Studies conclude that, first, there are several impacts of coal waste pollution - including impact on river ecosystem, impact on water conditions (PDAM Bengkulu), a domino effect which occurs in the lower river, as well as aesthetic impact on the environment; second, the precautions taken against the expansion of the environmental impact by companies in the upstream areas of Bengkulu are still limited only to the licensing instrument, while disregarding not stricter supervision; third, the most ideal concept to prevent the expansion of pollution should be one that involves various parties such as governments, communities, and stakeholders led by the provincial government; since authority conflict involves two different administrative regions.

Keywords: conflict of authority, impact of dumping, environmental pollution, the damage of riverecosystem, coal waste.

\section{A. Pendahuluan}

Tulisan ini dilatarbelakangi oleh konflik kewenangan antara Pemkot Bengkulu dan Pemkab Bengkulu Tengah. Hal ini bermula ketika dampak pencemaran limbah batu bara di hilir Sungai Bengkulu, dimana daerah aliran Sungai Bengkulu secara regional dan administratif terletak di dua kabupaten/kota di Provinsi Bengkulu, hulunya terletak di Kabupaten Bengkulu Tengah, sedangkan bagian hilir membelah Kota Bengkulu, meliputi dua kecamatan yaitu Muara Bangka Hulu dan Sungai Serut. Areal Daerah Aliran Sungai (DAS) Bengkulu mencapai 51.500 hektare (ha) yang terdiri atas tiga sub-DAS yaitu sub-DAS Susup seluas 9.890 ha, sub-DAS Rindu Hati 19.207 ha, dan sub-DAS Air Bengkulu Hilir 22.402 ha. $^{1}$

Berikut adalah gambaran detail DAS Sungai Bengkulu yang meliputi dua kabupaten yang meliputi Bengkulu Tengah dan Kota Bengkulu. Data yang ada memperlihatkan bahwa persentase luas yang masuk DAS di dua kabupaten tersebut kurang dari $50 \%$.

1 Oka Ardiansyah dan Rika Mustikasari, Gambaran Umum Permasalahan Pengelolaan Air DAS Air Bengkulu, Bengkulu: Telapak-Yayasan Ulayat Bengkulu, 2011, hlm. 4. 
J.T. Pareke dan David Aprizon Putra: Model Penyelesaian Konflik Kewenangan dalam Hal Timbulnya Dampak Dumping Limbah Batu Bara: Studi Kasus pada Pemerintah Kota Bengkulu dengan Pemerintah Kabupaten Bengkulu Tengah

Tabel 1.

Gambaran detail DAS Sungai Bengkulu

\begin{tabular}{|l|l|r|r|r|}
\hline Kabupaten & Kecamatan & Total Luas (ha) & $\begin{array}{l}\text { Luas yang } \\
\text { masuk DAS (ha) }\end{array}$ & $\begin{array}{l}\text { Persentase luas } \\
\text { yang masuk DAS }\end{array}$ \\
\hline \multirow{3}{*}{$\begin{array}{l}\text { Bengkulu } \\
\text { Tengah }\end{array}$} & Taba Penanjung & 25.413 & 25.413 & $100 \%$ \\
\cline { 2 - 5 } & Karang Tinggi & 13.804 & 13.252 & $96 \%$ \\
\cline { 2 - 5 } & Pondok Kelapa & 16.476 & 2.401 & $17 \%$ \\
\cline { 2 - 5 } & Talang Empat & 9.402 & 4.795 & $51 \%$ \\
\cline { 2 - 5 } & Total Kecamatan & 112.394 & 46.261 & $41 \%$ \\
\hline \multirow{3}{*}{ Kota } & Gading Cempaka & 2.395 & 2.395 & $100 \%$ \\
\cline { 2 - 5 } & Muara Bangkahulu & 2.387 & 1.623 & $68 \%$ \\
\cline { 2 - 5 } & Teluk segara & 1.673 & 1.221 & $73 \%$ \\
\cline { 2 - 5 } & Total Kecamatan & 15.170 & 5.239 & $34 \%$ \\
\hline
\end{tabular}

Sungai Bengkulu yang selama ini menjadi andalan bagi warga untuk berbagai keperluan, kini semakin tercemar akibat penambangan batu bara di bagian hulunya. ${ }^{2}$ Air Sungai Bengkulu yang notabene menjadi satu-satunya sumber air mineral untuk warga Kota Bengkulu menimbulkan polemik yang diakibatkan oleh pencemaran yang terjadi. Sebagai bukti dasar adanya pencemaran yang terjadi, berikut akan dipaparkan 4 hasil penelitian yang dilakukan oleh 4 otoritas berbeda, baik dinas maupun lembaga terkait mengenai pencemaran di DAS Sungai Bengkulu. Pertama, adalah hasil penelitian yang berasal dari LSM Ulayat Bengkulu: ${ }^{3}$

"Pencemaran yang terjadi di Sungai Bengkulu sudah melebihi ambang batas yang ditetapkan dalam Peraturan Menteri Kesehatan (Permenkes) Nomor 907 Tahun 2002 tentang Pengawasan Kualitas Air. Berdasarkan kajian yang dilakukan oleh LSM Ulayat pada 2010 terhadap kualitas air Sungai Bengkulu, pencemaran sudah jauh melebihi ambang batas dan kualitas air sangat buruk sehingga tidak layak diminum. Kajian ulayat terhadap tingkat kekeruhan, warna, kandungan zat besi, dan kandungan oksigen terlarut menyebutkan kondisi air Sungai Bengkulu sudah berada di ambang batas. Tingkat

2 Ibid, hlm. 4.

3 YUB Internal Report (Unpublished), Laporan Multipihak Berasan Air Bengkulu dalam Memperingati Hari Air Sedunia di Hotel Nala Sea Side, Bengkulu: Yayasan Ulayat Bengkulu, 2011. 
J.T. Pareke dan David Aprizon Putra: Model Penyelesaian Konflik Kewenangan dalam Hal Timbulnya Dampak Dumping Limbah Batu Bara: Studi Kasus pada Pemerintah Kota Bengkulu dengan Pemerintah Kabupaten Bengkulu Tengah

kekeruhan air mencapai $421 \mathrm{NTU}^{4}$ dari 5 NTU yang ditetapkan dalam Permenkes tersebut. Demikian juga dengan tingkat perubahan warna yang ditoleransi sebesar 15 PTCO $^{5}$ sudah berada pada angka 267 PTCO. Kandungan besi berada pada angka 0,76 mg per liter dari angka yang ditoleransi 0,30 mg per liter."

Kedua, hasil penelitian yang berasal dari penelitian yang dilakukan oleh Tim Gabungan Pemerintah Provinsi Bengkulu, yang terdiri dari 14 Satuan Kerja Perangkat Daerah (SKPD) menyatakan bahwa: ${ }^{6}$

"Setelah uji parameter terhadap air Bengkulu yang dilakukan ulayat, telah dilakukan juga uji parameter yang dilakukan oleh Tim Gabungan dari Pemerintah Provinsi Bengkulu. Pada awal Juni 2011, Pemerintah Provinsi Bengkulu membentuk Tim gabungan yang berisi 14 SKPD untuk melakukan pengambilan dan pengujian sampel di 17 titik berbeda di sepanjang Sungai Air Bengkulu. Hasilnya, pada 14 Juni 2011, melalui konferensi pers yang diselenggarakan Badan Lingkungan Hidup Provinsi Bengkulu yang dipimpin oleh Arifin Daud, telah dinyatakan bahwa air Sungai Bengkulu positif tercemar logam berat, mangan, dan serum. la juga menyatakan bahwa golongan kelas air Sungai Bengkulu turun menjadi golongan kelas III dari sebelumnya golongan kelas I. Dengan kata lain, air sungai Bengkulu hanya layak untuk aktivitas budidaya ikan dan persawahan."

Ketiga, hasil penelitian yang berasal dari penelitian tim Komisi Penanggulangan Bensin Bertimbal (KPBB) berkerjasama dengan Blacksmith Instituted Indonesia dan Kementerian Lingkungan Hidup Republik Indonesia menyatakan bahwa: ${ }^{7}$

"Selanjutnya, karena tidak adanya tindak lanjut untuk menyikapi persoalan tersebut, tepat pada tanggal 18 Agustus 2011 tim KPBB berkerjasama dengan

$4 \quad$ Nephelometric Turbidity Unit. Satuan NTU dipergunakan untuk menggambarkan tingkat kekeruhan air. Nephelometris dimaksudkan pada cara kerja alat pengukurnya, nephelometer mengukur seberapa banyak cahaya yang dipancarkan oleh partikel tersuspensi yang terdapat di dalam air. Semakin banyak cahaya yang terpancarkan, maka semakin tinggi nilai kekeruhannya. Sehingga, nilai NTU yang rendah mengindikasikan tingginya tingkat kejernihan air, sebaliknya nilai NTU yang tinggi mengindikasikan bahwa nilai kejernihannya rendah.

5 Platinum Cobalt (dinyatakan dengan satuan Pt.Co) dipergunakan untuk menggambarkan tingkat warna air. Penentuan warna yang sering digunakan adalah Visual Comparation hod yaitu dengan cara membandingkan air sampel dengan warna standar yang terbuat dari unsur Platinum (Pt) dan Cobalt (Co). Satuan dari warna adalah unit Pt.Co. Warna yang dianjurkan untuk keperluan air minum adalah 5-50 unit Pt.Co.

$7 \quad$ Ibid, hlm. 3-4. 
J.T. Pareke dan David Aprizon Putra: Model Penyelesaian Konflik Kewenangan dalam Hal Timbulnya Dampak Dumping Limbah Batu Bara: Studi Kasus pada Pemerintah Kota Bengkulu dengan Pemerintah Kabupaten Bengkulu Tengah

Blacksmith instituted Indonesia dan Kementerian Lingkungan Hidup kembali melakukan uji sampel terhadap air Bengkulu. Hasilnya bahkan lebih memprihatinkan, Sungai Air Bengkulu dinyatakan sudah tercemar logam membahayakan yaitu Merkuri $(\mathrm{Hg})^{8}$ dan Arsenic $(\mathrm{As})^{9}$. Parahnya lagi, kandungan merkuri dan arsenik tersebut kadarnya berada pada level mengkhawatirkan, yaitu mencapai 15 PPM dan 12 PPM di dua lokasi yang dijadikan sampel yaitu desa Penandingan dan Surau."

Keempat, hasil penelitian yang berasal dari penelitian tim terpadu yang dikoordinir Dinas Energi Sumber Daya Mineral (ESDM), yang terdiri dari 14 dinas dan badan berkepentingan menyatakan bahwa: ${ }^{10}$

"Sampel air Sungai Bengkulu yang diambil dari 30 titik akan diuji di tiga laboratorium untuk mengetahui tingkat pencemarannya. Sampel air yang diambil tersebut akan diuji di tiga laboratorium yaitu laboratorium milik Badan Lingkungan Hidup, Dinas Kesehatan, dan Dinas ESDM. Pengujian sampel tersebut dimaksudkan untuk membuktikan dugaan pencemaran Sungai Bengkulu akibat limbah batu bara dan karet seperti yang dikeluhkan masyarakat dan PDAM Kota Bengkulu. Hasil pemeriksaan terhadap 30 sampel tersebut akan dilaporkan ke Gubernur Bengkulu dan menjadi dasar untuk mengambil langkah selanjutnya. Sebelumnya, Kepala Dinas ESDM Provinsi Bengkulu Surya Gani mengatakan bahwa pihaknya akan memeriksa empat perusahaan tambang batu bara yang diduga mencemari Sungai Bengkulu. Empat perusahaan yang diperiksa aktivitasnya terkait dugaan pencemaran tersebut yakni PT Danau Mas Hitam (PT DMH), PT Inti Bara Perdana (PT IBP), PT Bukit Sunur (PT BS), dan PT Kesuma Raya Utama (PT KRU). Seluruh perizinan perusahaan tambang tersebut diterbitkan sebelum tahun 1990, yang artinya sudah puluhan tahun beraktivitas di hulu sungai tersebut."

8 Merkuri atau air raksa $(\mathrm{Hg})$ merupakan golongan logam berat dengan nomor atom 80 dan berat atom 200,6. Merkuri merupakan unsur yang sangat jarang dalam kerak bumi, dan relatif terkonsentrasi pada beberapa daerah vulkanik dan endapan-endapan mineral.

9 Arsenik adalah suatu unsur kimia metaloid (semilogam) golongan VA, berwujud bubuk putih, tanpa warna dan bau (karena itulah arsenik sangat dikenal dalam urusan racun-meracun makanan). Konsentrasi arsenik yang dianggap tidak berbahaya dalam air minum oleh WHO adalah kurang dari 10 ppb (part per billion). Selain karena arsenik menjadi bahan pestisida yang dipakai untuk menyemprot sayur dan buah, arsenik juga berpotensi mencemari perairan. Hal ini pernah menjadi masalah serius di Cina dan Bangladesh, dan sekitarnya pada tahun 2005.

10 Indo Tekhno PIus, "Bengkulu Uji Pencemaran Air Sungai Bengkulu”, http://www.indotekhnoplus.com/news/view/140/Bengkulu-Uji-Pencemaran-Air-Sungai, diakses 10 Desember 2012 pukul 09.00 WIB. 
J.T. Pareke dan David Aprizon Putra: Model Penyelesaian Konflik Kewenangan dalam Hal Timbulnya Dampak Dumping Limbah Batu Bara: Studi Kasus pada Pemerintah Kota Bengkulu dengan Pemerintah Kabupaten Bengkulu Tengah

Hasil penelusuran referensi yang telah dilakukan di atas, terutama terhadap hasil-hasil penelitian dan pengkajian memperlihatkan adanya sejumlah penelitian atau pengkajian sebelumnya yang menaruh perhatian yang sama dengan penelitian ini. Sekalipun demikian, fokus masalah yang menjadi perhatian utama dari penelitianpenelitian dan pengkajian-pengkajian selama ini memiliki perbedaaan yang signifikan dengan fokus masalah yang dikaji dalam penelitian ini.

Kajian-kajian terhadap kebijakan pencemaran yang dilakukan selama ini belum menukik sampai kepada masalah pergeseran kebijakan tata ruang dan perizinan dalam regulasi di tingkat daerah, yang kemudian berdampak terhadap perlunya dilakukan sebuah rekonstruksi terhadap kebijakan tata ruang dan perizinan yang bersifat partisipatoris dan responsif. Penegasan tentang orisinalitas studi ini bertujuan untuk menghindari pengulangan kajian terhadap sebuah tema dengan fokus studi yang sama.

Berdasarkan latar belakang yang telah dikemukakan, maka rumusan masalah dalam penelitian ini adalah bagaimana dampak kerusakan yang terjadi akibat dari pencemaran di daerah hilir aliran Sungai Bengkulu. Kemudian, bagaimana tindakan pencegahan yang dilakukan terhadap perluasan dampak pencemaran bagi perusahaan di daerah hulu Sungai Bengkulu. Terakhir, bagaimana konsep ideal pencegahan perluasan dampak pencemaran yang seharusnya dilakukan oleh Pemerintah Provinsi Bengkulu.

Studi ini bertujuan untuk mengetahui dan menjelaskan tentang titik tolak konflik kewenangan yang terjadi antara Pemkab Bengkulu Tengah dan Pemkot Bengkulu, konsep penyelesaian konflik kewenangan yang telah dilakukan diantara keduanya, dan selanjutnya berkenaan dengan konsep ideal penyelesaian konflik kewenangan tersebut. Metode yang digunakan dalam studi ini adalah normatif-sosiologis yang bersifat kualitatif. Dengan pendekatan normatif-sosiologis, studi ini menggunakan dua pendekatan, yaitu pendekatan sosial dan pendekatan yuridis normatif. Pendekatan sosial dipergunakan untuk menganalisis sikap, pandangan, dan tindakan aktor dalam praktik penyelesaian konflik kewenangan yang terjadi antara Pemkab Bengkulu Tengah dan Pemkot Bengkulu, sedangkan pendekatan yuridis normatif dipergunakan untuk menganalisis norma peraturan perundang-undangan dengan mengacu pada nilai-nilai kesejahteraan dan keadilan dalam masyarakat dan prinsip kepastian hukum. Analisis yang dilakukan bersifat kualitatif yang tidak menekankan pada kuantitas data, tetapi pada kualitasnya. Data primer diperoleh melalui wawancara, sedangkan data sekunder diperoleh dengan penelusuran dokumen peraturan perundang-undangan, buku, jurnal hukum, hasil-hasil penelitian, dan putusan pengadilan yang relevan untuk menjelaskan permasalahan dalam studi ini. 
J.T. Pareke dan David Aprizon Putra: Model Penyelesaian Konflik Kewenangan dalam Hal Timbulnya Dampak Dumping Limbah Batu Bara: Studi Kasus pada Pemerintah Kota Bengkulu dengan Pemerintah Kabupaten Bengkulu Tengah

\section{B. Gambaran Kegiatan-Kegiatan Kritis di Daerah Hulu}

Berikut adalah lima aktivitas yang dianggap membahayakan dalam hubungannya dengan sumber daya air di DAS Air Bengkulu, yaitu: 1) pertambangan di daerah hulu; 2) pengumpulan tailing limbah batu bara di sungai; 3) pabrik karet; 4) PDAM sebagai penyedia air; dan 5) pertanian (agroforestri dan pertanian padi irigasi). Aktivitas kritis tersebut dipilih berdasarkan ketergantungannya pada ketersediaan air dan sebaliknya, serta besarnya pengaruh kegiatan-kegiatan ini terhadap kondisi sumber daya air di DAS Air Bengkulu. Pertimbangan yang dipakai adalah besarnya air yang dibutuhkan oleh aktivitas kritis tersebut jika dibandingkan aktivitas ekonomi lainnya dan juga seberapa besar aktivitas-aktivitas ekonomi tersebut bergantung pada ketersediaan air (misalnya kerugian apa yang akan terjadi ketika ketersediaan air menurun).

\section{Pertambangan di Daerah Hulu}

Terdapat empat perusahaan pertambangan batu bara di daerah hulu DAS Air Bengkulu yaitu: PT DMH; PT IBP; PT BS; dan PT ETA. Dua perusahaan pertama yang disebutkan beroperasi di Air Kandis di sebelah selatan Bukit Sunur, Desa Taba Penanjung, Kabupaten Bengkulu Tengah di lahan seluas 800 ha. Tidak ada informasi yang didapatkan tentang kegiatan operasional dan kondisi ketenagakerjaan dari perusahaan ini. Hal ini disebabkan oleh sulitnya akses ke perusahaan dan juga karena keterbatasan waktu dan sumber daya dalam pelaksanaan Career Development Project (CDP).

Pada bulan Agustus 2008, Gubernur Bengkulu meminta penutupan dua pertambangan batu bara di hulu DAS Air Bengkulu: PT BS dan PT DMH. Penutupan ini terkait temuan lapang yang kegiatan penambangan perusahaan-perusahaan ini dilakukan di kawasan Hutan Lindung Rindu Hati tanpa mendapat persetujuan dari Kementerian Kehutanan. Izin usaha perusahaan tersebut diberikan kembali pada awal 2010 ketika perusahaan menghentikan penambangan di hutan lindung. Pertambangan batu bara di bagian hulu adalah sumber utama produksi batu bara di Provinsi Bengkulu. Terdapat enam konsesi pertambangan batu bara di provinsi dengan total produksi sekitar 1,8 juta ton pada tahun 2009. Empat perusahaan di antaranya berlokasi di bagian hulu DAS Air Bengkulu. Saat ini, pemerintah daerah telah memberikan izin lain untuk perusahaan tambang batu bara, PT Bio Energi, untuk beroperasi di konsesi tambang batu bara yang baru di daerah hulu DAS Air Bengkulu. Pertambangan batu bara di Provinsi Bengkulu diklasifikasikan dalam pertambangan skala kecil dengan rata-rata 50 tenaga kerja lokal pada tiap perusahaan. Sebagian besar tenaga lokal ini, bekerja sebagai pencuci batu bara dan sebagian lainnya sebagai petugas keamanan. Kegiatan pertambangan terbukti telah 
J.T. Pareke dan David Aprizon Putra: Model Penyelesaian Konflik Kewenangan dalam Hal Timbulnya Dampak Dumping Limbah Batu Bara: Studi Kasus pada Pemerintah Kota Bengkulu dengan Pemerintah Kabupaten Bengkulu Tengah

menyebabkan terjadinya deforestasi, erosi lahan, dan pencemaran sungai. Seperti halnya aktivitas pertambangan lain, pertambangan batu bara juga berkontribusi dalam degradasi lingkungan, air dan tanah.

a. Pencemaran air

Pencemaran air adalah masalah penting di DAS Air Bengkulu. Penambangan batu bara secara langsung berkontribusi menyebabkan pencemaran air, terutama selama proses ekstraksi pemisahan batu bara dan sulfur. Sisa tambang mencemari sungai, menyebabkan air keruh dan asam, serta menyebabkan pengendapan dan pendangkalan di sungai. Sisa tambang yang mengandung bahan kimia berbahaya bagi kesehatan manusia jika air yang terkontaminasi bahan tersebut dikonsumsi. Sisa tambang mengandung Sulfur (S), Merkuri (Hg), Hidrogen sianida (HCN), Mangan (Mn), Asam sulfat (H2SO4), dan Timbal (Pb). Hg dan Pb adalah logam berat yang di antaranya dapat memicu terjadinya berbagai penyakit kanker. Selain itu, air sungai juga tercemari oleh proses pencucian batu bara. Pencucian dilakukan dengan menggerinda batu bara menjadi ukuran-ukuran kecil dan kemudian mencucinya. Potongan-potongan tersebut dimasukkan ke dalam tangki yang dipenuhi air yang batu bara berkualitas murni akan mengambang sedangkan yang lainnya akan tenggelam.

\section{b. Pencemaran tanah}

Operasi pertambangan juga memengaruhi kondisi tanah. Operasi pertambangan terbuka menyisakan sebuah lubang besar yang tidak dapat ditutup lagi karena lubang sudah mengandung air dengan kadar asam tinggi yang mengandung Besi (Fe), Mn, Sulfat (SO4), dan Pb. Kehadiran Fe dan Mn dalam jumlah besar dapat menghambat pertumbuhan tanaman, sedangkan SO4 dapat memengaruhi kesuburan tanah dan $\mathrm{pH}$ dan kehadiran $\mathrm{Hg}$ dan $\mathrm{Pb}$ berpotensi untuk meracuni tanaman.

\section{Pengumpulan Tailing Batu Bara di Sungai}

Beberapa sumber mengatakan bahwa pada tahun 1980 kedalaman sungai Air Bengkulu mencapai hampir lima meter di daerah hilir dan airnya jernih. Namun sejak penambangan batu bara mulai beroperasi, bentuk pemanfaatan lain dari sungai seperti perikanan dan transportasi mengalami penurunan. Sungai pun mengalami pendangkalan. Pendangkalan di sungai Air Bengkulu dapat disebabkan oleh beberapa faktor, misalnya pencucian batu bara, deforestasi, dan erosi. Deposit batu bara menjadi penyebab utama pendangkalan sungai dikarenakan penimbunan yang terjadi di dasar sungai sejak pertambangan beroperasi pada tahun 1980. Masyarakat lokal melihat tailing di sungai Air Bengkulu sebagai kesempatan untuk mendapat penghasilan tambahan. Masyarakat dari desa pantai di hilir mulai mengumpulkan tailing pada tahun 1999. Pada waktu itu, satu sak (50 kg) batu bara diberikan harga 
J.T. Pareke dan David Aprizon Putra: Model Penyelesaian Konflik Kewenangan dalam Hal Timbulnya Dampak Dumping Limbah Batu Bara: Studi Kasus pada Pemerintah Kota Bengkulu dengan Pemerintah Kabupaten Bengkulu Tengah

hingga Rp10.000,00. Menjual produk tailing tidak mudah karena hanya sedikit pihak yang mau membelinya. Kelompok yang aktif menjadi pembeli tailing batu bara hasil pengumpulan masyarakat ini biasanya para pengusaha peternak ayam, pandai besi, dan pemilik warung makan yang berada di sekitar lokasi pengumpulan.

Dengan permintaan batu bara dalam skala sedang dan rendah menyebabkan usaha bisnis meningkat. Masyarakat desa lain sepanjang Sungai Air Bengkulu seperti mereka yang tinggal di Desa Pasar Bengkulu, Tanjung Agung, Kembang Seri, Pondok Kelapa, Surabaya, Semarang, dan Penanding (Kota Bengkulu dan Kabupaten Bengkulu Tengah) mulai mengumpulkan limbah batu bara sebagai pekerjaan alternatif. Praktik tersebut tumbuh pesat. Pencari limbah tailing batubara dapat mendapat Rp50.000,00 hingga Rp100.000,00 per hari ketika mereka menjual 5-8 karung batu bara per hari (masing-masing $25 \mathrm{~kg}$ ) dengan harga per karung Rp15.000,00 hingga Rp17.500,00. Nelayan bekerja dari pukul 08.00 sampai dengan 17.00. Data menunjukkan bahwa dalam satu bulan, masing-masing kelompok nelayan tailing yang berjumlah 8 sampai dengan 10 orang menjual hasil tailing-nya sekitar 30-50 ton ke luar kecamatan. Ada sekitar 50 kelompok nelayan tailing di sepanjang Sungai Air Bengkulu yang terorganisasi oleh pembeli pengumpul batu bara/tengkulak dan mereka menjual tailing batu bara itu keluar Bengkulu, seperti ke Jakarta, Lampung, dan Linggau (Sumatra Selatan). Namun demikian, nelayan tailing batu bara di Sungai Air Bengkulu mengalami keresahan karena Dinas ESDM Provinsi Bengkulu mulai melarang aktivitas tersebut karena kegiatan ini tidak mempunyai izin resmi.

\section{Pabrik Karet}

Dua pabrik karet yang terletak di sepanjang Sungai Air Bengkulu: PT. Bukit Angkasa Makmur (BAM) dan PT. BH, terletak di Kecamatan Talang Empat, Kabupaten Bengkulu Tengah. Bahan baku pabrik dikirimkan dari banyak kecamatan di Kabupaten Bengkulu Tengah dimana perkebunan karet banyak dimiliki oleh masyarakat dan beberapa perkebunan besar yang juga dimiliki oleh perusahaan pabrik karet itu. Tenaga kerja pabrik berasal dari masyarakat sekitar, tetapi kebanyakan pegawai tingkat tingginya berasal dari Jawa. Penulis mendapat kesulitan mendapatkan akses informasi dari industri pabrik-pabrik karet ini. Pabrik PT BH yang dibangun tahun 2003 merupakan pabrik pengolahan karet yang berlokasi di Jalan Bengkulu Curup KM. 15, Desa Taba Penanjung, Kecamatan Karang Tinggi, Kabupaten Bengkulu Tengah. Pabrik seluas $92.500 \mathrm{~m}^{2}$ tersebut memproduksi limbah minyak yang dapat mencemari sungai. Limbah minyak tersebut berbentuk limbah padat yang terdiri dari sisa karet, endapan, lembaran plastik, pasir dan potongan-potongan kayu yang berbahaya bagi kesehatan dan dapat merusak nilai estetika sungai dikarenakan menimbulkan 
J.T. Pareke dan David Aprizon Putra: Model Penyelesaian Konflik Kewenangan dalam Hal Timbulnya Dampak Dumping Limbah Batu Bara: Studi Kasus pada Pemerintah Kota Bengkulu dengan Pemerintah Kabupaten Bengkulu Tengah

pengendapan dan bau tidak sedap. Asap dari cerobong pabrik pun mengeluarkan bau busuk yang tercium hingga $20 \mathrm{~km}$ jauhnya.

Pabrik PT. BAM yang dibangun pada tahun 1997 berlokasi di Desa Kembang Seri, Kecamatan Talang Empat, Kabupaten Bengkulu Tengah dan mencakupi area seluas $33.552 \mathrm{~m}^{2}$. Pabrik ini memproduksi crumb rubber dengan kapasitas 800 ton/bulan dan beroperasi selama 16 jam per hari dan 6 hari per minggu. Pabrik ini menggunakan mesin-mesin seperti mesin pre-breaker, hammer mill, creeper, pemotong, mesin pemroses, dan juga pengering.

\section{Penyedia Air Publik}

PDAM yang dibentuk pada tahun 1929 pada awalnya mengambil air dari sungai Bengkulu dengan stasiun distilasi air yang berlokasi di Desa Surabaya,Kota Bengkulu. Pada tahun 1980, kualitas air mulai mengkhawatirkan, maka dari itu PDAM membangun fasilitas baru di dekat Sungai Nelas. Saat ini, PDAM melayani 21.000 rumah tangga di Kota Bengkulu meskipun tidak semua konsumen mendapatkan air yang intake-nya berasal dari Sungai Air Bengkulu. Sebanyak 14.700 rumah tangga (70\%) mendapat air yang intake-nya diambil dari Sungai Nelas, sedangkan 6.300 rumah tangga (30\%) mendapat air yang sumber airnya berasal dari Sungai Air Bengkulu. Konsumen yang mendapat air dari Sungai Air Bengkulu adalah yang tinggal di tiga kecamatan di Kota Bengkulu, yaitu: Kecamatan Muara Bangkahulu; Telur Segara; dan Sungai Serut.

Sungai Air Bengkulu saat ini sudah tidak memenuhi standar kualitas sumber air baku PDAM. Ulayat dan laboratorium PDAM mempelajari parameter fisik dan kimia air sungai, seperti temperatur, bau, rasa, warna, kekeruhan, konduktivitas, TSS, TDS, BOD, COD, kandungan logam, pH, dan DO. ${ }^{11}$ Contoh sampel air untuk pengamatan ini diambil dari bulan Juni sampai dengan Desember tahun 2008 di lima stasiun hasil pengamatan dibandingkan dengan standar kualitas yang ditetapkan Peraturan Pemerintah Daerah Nomor 6 Tahun 2005 tentang Ambang Batas Maksimum Air untuk Sungai Lintas Kabupaten di Propinsi Bengkulu dan Peraturan Menteri Kesehatan No. 907 tahun 2002 tentang Syarat-Syarat dan Pengawasan Kualitas Air Minum. Jelas terlihat bahwa beberapa parameter telah melebihi angka kualitas air yang ditetapkan oleh pemerintah daerah maupun Menteri Kesehatan. Ulayat pernah melakukan kampanye tentang pencemaran sungai yang terjadi melalui beberapa kegiatan, yakni: (i) FGD dengan konsumen PDAM; (ii) mengumumkan hasil studi sebagai bagian dari akses pelayanan publik terhadap informasi; dan (iii) diskusi dengan walikota, perwakilan masyarakat dan pemerintahan kota, dan BLH provinsi. 
J.T. Pareke dan David Aprizon Putra: Model Penyelesaian Konflik Kewenangan dalam Hal Timbulnya Dampak Dumping Limbah Batu Bara: Studi Kasus pada Pemerintah Kota Bengkulu dengan Pemerintah Kabupaten Bengkulu Tengah

Berdasarkan informasi dari petugas PDAM, perlakuan terhadap air yang berasal dari sungai Air Bengkulu tidak memungkinkan dilakukan secara teknik semata. Cara lain untuk menghentikan distribusi air tercemar adalah dengan menutup sementara intake Sungai Air Bengkulu dan hanya menggunakan air dari Sungai Nelas selama rehabilitasi Sungai Air Bengkulu dilakukan. Namun, PDAM dan pemerintah daerah tidak mempunyai cukup anggaran untuk membangun fasilitas tambahan di Sungai Nelas.

Setelah kampanye dilakukan, PDAM menyediakan tangki-tangki air yang bisa dikonsumsi di beberapa lokasi di tiga kecamatan yang menerima air tercemar dari Sungai Air Bengkulu. Air bersih tersebut disediakan untuk mengakomodasi kebutuhan air bersih masyarakat selama menunggu perbaikan kualitas air sungai. Namun, penyediaan air bersih dalam tangki ini hanya berlangsung selama beberapa bulan saja. Konsumen PDAM di tiga kecamatan itu kembali mengonsumsi air PDAM yang diambil dari intake yang tercemar yang sesungguhnya tidak layak dikonsumsi.

Kualitas air Sungai Air Bengkulu yang buruk adalah isu serius dan merupakan persoalan dominan dalam pengelolaan sumber daya air di DAS Air Bengkulu. PDAM tidak sanggup untuk mengolah dengan baik air yang tercemar, yang merupakan sumber utama intake air Kota Bengkulu. Kualitas air yang didistribusikan masih di bawah standar kualitas nasional dan standar provinsi. Pemenuhan kebutuhan air bersih adalah aspek penting kesehatan masyarakat dan hal ini merupakan tanggung jawab pemerintah. Oleh karena itu, pemerintah Kota Bengkulu harus menemukan solusi dan PDAM harus menghentikan pengambilan intake dari Sungai Air Bengkulu yang tercemar dan menemukan sumber alternatif lain. Sumber pencemaran khususnya disebabkan oleh pertambangan batu bara dan pabrik karet di daerah hulu dan tengah DAS. Aktivitas kedua jenis industri tersebut tersebut tidak mempraktikkan proses produksi yang baik, sehingga dapat dikategorikan sebagai suatu kejahatan lingkungan. Tidak hanya sumber air PDAM saja yang terpengaruh oleh pencemaran ini, tetapi juga biota-biota sungai seperti berbagai jenis ikan. Maka diperlukan sebuah rangkaian usaha (dengan pembuatan sebuah peraturan daerah atau dibuat kesepakatan tertulis antara pemerintah dan perusahaan) yang membuat perusahaan dapat memperbaiki proses produksinya dan mengelola air limbah hasil proses produksinya.

\section{Agroforestri di Daerah Hulu}

Produk utama pertanian di daerah hulu adalah kopi dan lada. Para petani umumnya mengolah lahan milik sendiri untuk konsumsi sendiri (subsistem) sehingga perambahan hutan lindung masih terus terjadi di daerah hulu DAS Air Bengkulu. Ratarata sebuah keluarga memiliki 1,5 ha lahan pertanian yang terdiri dari sebuah plot 
J.T. Pareke dan David Aprizon Putra: Model Penyelesaian Konflik Kewenangan dalam Hal Timbulnya Dampak Dumping Limbah Batu Bara: Studi Kasus pada Pemerintah Kota Bengkulu dengan Pemerintah Kabupaten Bengkulu Tengah

kecil kebun kopi dan diselingi lada, buah-buahan dan pepohonan lain, serta satu plot untuk lahan padi sawah. Hasil panen padi sawah yang ditanam petani adalah untuk dikonsumsi sendiri. Cara petani membersihkan lahan adalah dengan membakar ranting dan rumput kering lainnya, kemudian menanam bibit tanaman kopi. Selama musim tanam, petani akan membersihkan rumput-rumput dan juga menggunakan pestisida (digunakan 3 liter setiap 6 bulan) ketika tanaman kopi berumur 3 bulan. Biji kopi dipanen ketika tanaman kopi berumur 4 tahun. Setiap tahunnya, kebun kopi dipanen hanya selama musim panen buah, yaitu pada bulan Maret-April. Jarak antara musim panen dan pascapanen adalah 3 bulan.

Di samping tanaman kopi, petani juga menanam lada, buah-buahan, dan tanaman kayu keras lainnya di sela-sela kebun kopi. Beberapa petani mendapat pembagian lahan seluas 1 ha di dalam hutan lindung, yang kemudian ditanami kopi. Para petani akan bekerja di kebun kopinya selama 10 bulan musim tanam dengan melakukan berbagai kegiatan yaitu penyiangan, pemangkasan, dan penyemprotan herbisida dan pestisida. Mereka tinggal di pondok kecil yang dibangun di kebun selama kegiatan tersebut. Proses pemanenan kopi (yang disebut mutil) dilanjutkan dengan kegiatan pengeringan. Petani akan membawa biji kopi ke desa dan menjualnya pada tengkulak. Sebagian petani akan menggiling biji kopi sebelum menjualnya. Petani kopi yang tinggal di hutan membutuhkan biaya transpor tambahan untuk membawa hasil panennya ke desa.

Kebun kopi menghasilkan rata-rata 400 kg kopi olahan per ha (kopi kering yang belum dihaluskan, yang di tingkat lokal dikenal dengan istilah beras kopi). Hasil panen dijual dengan harga Rp 10.000/kg. Sebagian besar petani juga menanam lada di selasela kebun kopi; memproduksi rata-rata $40 \mathrm{~kg}$ lada per tahun dengan harga jual Rp18.000,00/kg. Masyarakat desa yang memiliki sawah, tidak menjual hasil panennya, melainkan hanya untuk konsumsi sendiri. Padi ditanam dua kali per tahun. Total keseluruhan musim tanam padi adalah 14 minggu, yang dimulai dengan pembibitan pada minggu ke-1, pengolahan lahan minggu ke-2, dan penanaman pada minggu ke-3. Pemberian pupuk dilakukan pada minggu ke-5 dan ke-10. Biaya produksi mencakup keseluruhan proses produksi, termasuk pengolahan lahan, pembelian pupuk, pestisida, biaya tenaga kerja, dan transportasi. Lahan sawah diolah dengan traktor. Pupuk kimia digunakan ketika petani mampu membelinya. Selain itu terdapat juga sawah irigasi di DAS Air Bengkulu, dibawah skema irigasi yang dibuat oleh Kementerian PU Jakarta yang mencakup area seluas 2.416 ha. Produksi padi per ha untuk petani di daerah hulu lebih sedikit dibanding petani di hilir. 
J.T. Pareke dan David Aprizon Putra: Model Penyelesaian Konflik Kewenangan dalam Hal Timbulnya Dampak Dumping Limbah Batu Bara: Studi Kasus pada Pemerintah Kota Bengkulu dengan Pemerintah Kabupaten Bengkulu Tengah

\section{Dampak Kerusakan yang Terjadi Akibat Pencemaran di Daerah Hilir Aliran Sungai Bengkulu}

Dampak kerusakan yang terjadi akibat pencemaran di daerah hilir aliran Sungai Bengkulu yang berhasil didata dalam penelitian ini, meliputi beberapa jenis atau bentuk yaitu sebagai berikut:

\section{Dampak terhadap Kerusakan Ekosistem Sungai}

Direktur Wahana Lingkungan Hidup (WALHI) Bengkulu, Beni Ardiansyah, mengatakan bahwa telah terjadi kerusakan ekosistem di DAS Sungai Bengkulu. Menurut beliau, hasil penelitian WALHI menemukan bahwa telah terjadi pengurangan populasi makhluk hidup baik hewani maupun nabati. Sebagai bukti zaman dahulu kala masih terdapat banyak ikan di Sungai Bengkulu dan sangat mudah untuk mencarinya, tidak seperti sekarang. Selain itu, telah terjadi pula kerusakan pada ekosistem nabati, di mana jumlah ikan menjadi berkurang oleh karena faktor limbah dan faktor makanan, sehingga tumbuhan-tumbuhan sungai dan ganggang-ganggang air yang juga menjadi berkurang.

\section{Dampak terhadap Kondisi Air (PDAM Kota Bengkulu)}

Kualitas air sungai Bengkulu yang notabene merupakan sungai yang menjadi satusatunya sumber air PDAM untuk Kota Bengkulu telah mengalami penurunan kualitas. ${ }^{12}$ Oka Ardiansyah, Direktur Eksekutif Yayasan Ulayat Bengkulu menambahkan, kualitas air yang dulunya berada di kelas 1 , air ini dulunya bisa dikonsumsi langsung, sekarang berada di kelas 3 yang peruntukannya adalah hanya untuk pertanian dan perikanan. Hal ini sangat merugikan warga karena warga Kota Bengkulu pengguna air dari PDAM menggunakan air yang tidak layak dikonsumsi.

\section{Efek Domino yang Terjadi di Hilir Sungai}

Fenomena yang sangat luar biasa berdampak atas pencemaran limbah batu bara adalah terjadinya kegiatan pengumpulan batu bara di daerah Muara Sungai Bengkulu yang terletak di Kelurahan Pasar Bengkulu. Terjadi efek domino di sini, yaitu pola hidup masyarakat sekitar lokasi itu berubah dan ditandai dengan pola sosial dan ekonomi yang juga berubah secara drastis.

Salah seorang warga Pasar Bengkulu mengatakan bahwa masyarakat di sini sekarang sudah banyak beralih profesi, yang dulunya nelayan sekarang menjadi pengumpul batu bara. Hal terburuk yang terjadi adalah dari tatanan sosialnya, dimana pola sosial yang terjadi sudah tidak sehat, banyak anak-anak putus sekolah karena tergiur dengan pekerjaan yang bisa mendapat uang Rp25.000,00 sampai dengan Rp50.000,00 per hari. Hal ini sangat berpengaruh pada anak-anak, terlebih kepada 
J.T. Pareke dan David Aprizon Putra: Model Penyelesaian Konflik Kewenangan dalam Hal Timbulnya Dampak Dumping Limbah Batu Bara: Studi Kasus pada Pemerintah Kota Bengkulu dengan Pemerintah Kabupaten Bengkulu Tengah

pendidikan, dan itu sudah terbukti ada anak-anak yang meninggalkan sekolah, bahkan benar-benar berhenti sekolah.

\section{Dampak terhadap Estetika Lingkungan}

Dengan semakin banyaknya zat organik yang dibuang ke lingkungan perairan, maka perairan tersebut akan semakin tercemar yang biasanya ditandai dengan bau yang kurang sedap dan warna yang berubah menjadi kotor. Dampak yang ditimbulkan tersebut dapat mengurangi nilai estetika lingkungan sekitar hilir sungai Bengkulu.

\section{Tindakan Pencegahan yang Dilakukan terhadap Perluasan Dampak Pencemaran bagi Perusahaan di Daerah Hulu Sungai Bengkulu}

Dumping yang selama ini mengkaji eksplorasi tambang batu bara adalah dumping area, dimana sebuah perusahaan yang mengelola tambang batu bara melakukan dumping di lokasi yang masih berupa kawasan project area; perizinan dan pengaturan mengenai itu dilakukan secara paket pada saat proses pengajuan izin lingkungan dan analisis mengenai dampak lingkungan (AMDAL) pada awal pendirian perusahaan. ${ }^{13}$

Dumping area merupakan salah satu aktivitas tambang yang diperbolehkan, tentunya tetap dalam pengawasan. Dumping limbah yang dilakukan tidak boleh keluar wilayah project area yang telah ditentukan dengan kekuatan hukum sebelumnya. Apabila terjadi pelanggaran, maka pihak Dinas ESDM berhak menindak dan memberi sanksi. Jadi boleh dikatakan, kewenangan Dinas Energi dan Sumber Daya Mineral hanya mencakup pada lingkup kawasan yang telah diperizinkan sebelumnya dengan dasar AMDAL dan izin lingkungan perusahaan terkait. ${ }^{14}$ Apabila tugas, pokok, dan fungsi (tupoksi) pelanggaran melebihi kewenangan itu, maka Badan Lingkungan Hidup terkaitlah yang mengambil alih.

Kewenangan masalah dumping dalam penelitian ini ada di bawah Badan Lingkungan Hidup karena dampaknya sudah keluar dari wilayah project area. Secara administratif, wilayah atau objek penelitian yaitu Daerah Aliran Sungai (DAS) Sungai Bengkulu terletak di dua wilayah administratif, yaitu Kabupaten Bengkulu Tengah dan Kota Bengkulu. Oleh karena itu, kewenangan penindakan secara lebih proporsional terletak pada Badan Lingkungan Hidup Provinsi tentunya dengan tidak meninggalkan posisi Badan Lingkungan Hidup Bengkulu tengah. Berikut data yang diperoleh dari hasil wawancara dan penelusuran data beberapa perusahaan batu bara yang menjadi objek penelitian; semua memiliki dua dasar hukum mengenai dumping

13 Hasil wawancara dengan Kepala Bidang Perizinan dan Pengelolaan Energi Dinas Energi dan Sumber Daya Mineral Provinsi Bengkulu pada tanggal 5 Februari 2013.

14 Data dari Dinas Energi dan Sumber daya Mineral, diambil pada tanggal 4 Februari 2013. 
J.T. Pareke dan David Aprizon Putra: Model Penyelesaian Konflik Kewenangan dalam Hal Timbulnya Dampak Dumping Limbah Batu Bara: Studi Kasus pada Pemerintah Kota Bengkulu dengan Pemerintah Kabupaten Bengkulu Tengah

limbah yaitu yang terdapat dalam :

\section{Izin Khusus Pembuangan Air Limbah ke Media Lingkungan Hidup untuk Dumping Air Asam Tambang}

Air Asam Tambang (AAT) merupakan cairan hasil dari proses pengolahan limbah di kolam-kolam pencucian batu bara. AAT ini diproses dan diolah sehingga keasaman air, $\mathrm{pH}$ air, dan kandungan zat berbahaya lainnya bisa sesuai dan menjadi normal untuk kemudian bisa dialirkan ke aliran air/sungai. ${ }^{15}$

Untuk kondisi dumping ini, terdapat dalam izin khusus yaitu izin pembuangan air limbah ke media lingkungan hidup. Pemkab Bengkulu Tengah telah mengeluarkan surat izin tersebut tertanggal 20 Desember 2011 dengan masa berlaku izin selama 6 tahun, jadi izin tersebut berakhir terhitung pada tanggal 20 Desember 2017.

Surat izin tersebut, dalam Pasal 2, disebutkan secara rinci kewajiban pemegang izin, yaitu untuk menjaga kelestarian fungsi lingkungan hidup. Setiap usaha/kegiatan wajib memiliki izin pembuangan air limbah ke media lingkungan hidup dengan ketentuan sebagai berikut:

a. melaksanakan ketertiban umum dan membina hubungan baik dengan tetangga sekitar;

b. menjaga kesehatan, ketertiban, dan keindahan lingkungan usaha;

c. bertanggung jawab terhadap kerusakan dan atau pencemaran lingkungan yang diakibatkan oleh usaha dan atau kegiatan tersebut;

d. bersedia dipantau dampak lingkungan dari usaha dan atau kegiatannya oleh pejabat yang berwenang;

e. wajib menjaga kelestarian sumber daya alam dan lingkungan hidup lokasi dan sekitar tempat usaha dan atau kegiatan;

f. wajib melaporkan pengelolaan lingkungan setiap 6 (enam) bulan ke Badan Lingkungan Hidup Kabupaten Bengkulu Tengah;

g. jika ketentuan-ketentuan sebagaimana diatur di atas tidak dilaksanakan sebagaimana mestinya, maka akan dikenakan sanksi sesuai perundangundangan yang berlaku.

Kemudian untuk lokasi titik penaatan di perusahaan ini, ditetapkan menjadi 4 Pit (Lokasi Penaatan), yaitu Pit Lebong Atas, Pit Talang Seginim, Pit Getuk Garut, dan Pit Kemumu. Keempat titik inilah yang menjadi titik penaatan sebagai acuan yang disepakati oleh kedua belah pihak (pemerintah dan pihak pertambangan) sebagai tempat pengambilan dan pengujian sampel air limbah, sekaligus sebagai tempat pemantauan pengecekan kebutuhan lainnya yang berhubungan dengan pengolahan

Hasil wawancara dengan Bapak Iwan, seorang Sarjana Teknik Pertambangan yang sekarang bekerja di salah satu perusahaan batu bara nasional. 
J.T. Pareke dan David Aprizon Putra: Model Penyelesaian Konflik Kewenangan dalam Hal Timbulnya Dampak Dumping Limbah Batu Bara: Studi Kasus pada Pemerintah Kota Bengkulu dengan Pemerintah Kabupaten Bengkulu Tengah

limbah dan pembuangan (dumping) limbah.

Ada beberapa kriteria penilaian dalam bentuk evaluasi terhadap perusahaanperusahaan pertambangan batu bara yang dilakukan oleh Badan Lingkungan Hidup Provinsi Bengkulu. Berikut data hasil evaluasi yang dilakukan tim PROPER (Program Penilaian dan Peringkat Perusahaan) Badan Lingkungan Hidup Provinsi Bengkulu 2012 yang berhasil terekam dalam penelitian ini:

Tabel 2.

Hasil Program Penilaian dan Peringkat Perusahaan oleh Badan Lingkungan Hidup Provinsi Bengkulu

\begin{tabular}{|c|c|c|}
\hline Pengelolaan Limbah Cair & Penaatan & Keterangan \\
\hline $\begin{array}{l}\text { Ketaatan terhadap titik } \\
\text { penaatan pemantauan }\end{array}$ & $75 \%$ & $\begin{array}{c}\text { Dari empat outlet yang dimiliki } \\
\text { hanya melakukan tiga outlet } \\
\text { (titik penaatan) }\end{array}$ \\
\hline Ketaatan terhadap pelaporan & $0 \%$ & $\begin{array}{c}\text { Perusahaan hanya melaporkan } \\
\text { tiga outlet dari empat outlet yang } \\
\text { harus dilaporkan }\end{array}$ \\
\hline $\begin{array}{l}\text { Ketaatan terhadap parameter } \\
\text { baku mutu }\end{array}$ & $100 \%$ & $\begin{array}{l}\text { Perusahaan telah melakukan } \\
\text { pemantauan kualitas air limbah } \\
\text { sesuai dengan parameter yang } \\
\text { dipersyaratkan }\end{array}$ \\
\hline $\begin{array}{c}\text { a. Ketaatan terhadap } \\
\text { pemenuhan baku mutu } \\
\text { b. Ketaatan terhadap } \\
\text { pemenuhan baku mutu } \\
\text { terhadap pemantauan PROPER }\end{array}$ & $100 \%$ & $\begin{array}{l}\text { Seluruh parameter telah } \\
\text { memenuhi baku mutu air limbah } \\
\text { Seluruh parameter telah } \\
\text { memenuhi baku mutu air limbah }\end{array}$ \\
\hline
\end{tabular}


J.T. Pareke dan David Aprizon Putra: Model Penyelesaian Konflik Kewenangan dalam Hal Timbulnya Dampak Dumping Limbah Batu Bara: Studi Kasus pada Pemerintah Kota Bengkulu dengan Pemerintah Kabupaten Bengkulu Tengah

\begin{tabular}{|l|l|c|}
\hline Ketaatan terhadap izin & Taat & $\begin{array}{c}\text { Keputusan Kepala Badan } \\
\text { Lingkungan hidup Bengkulu } \\
\text { Tengah tanggal 20 Desember 2011 }\end{array}$ \\
\hline Ketaatan terhadap ketentuan teknis & Tidak taat & $\begin{array}{c}\text { Belum memenuhi seluruh } \\
\text { ketentuan teknis yang } \\
\text { dipersyaratkan }\end{array}$ \\
\hline
\end{tabular}

Sumber: Monograf Badan Lingkungan Hidup Provinsi Bengkulu

Berdasarkan evaluasi pengendalian pencemaran air dan juga ketentuan di atas, maka perusahaan taat terhadap parameter baku mutu, pemenuhan baku mutu limbah dan ketaatan terhadap izin, tetapi perusahaan tidak taat terhadap pemenuhan titik penaatan pemantauan, pelaporan dan ketentuan teknis (belum memasang flowmeter) yang sesuai dengan peraturan perundang-undangan lingkungan yang berlaku. ${ }^{16} \mathrm{Hal}$ ini membuktikan bahwa memang benar pelaksanaaan dumping belum sesuai dengan aturan.

\section{Analisis Mengenai Dampak Lingkungan (AMDAL) beserta Izin Lingkungan untuk Dumping Area}

Top soil adalah lapisan tanah dan mineral tanah yang berasal dari proses awal pengerukan lapisan kerak bumi, di mana kurang lebih ketebalan lapisan ini minimal 50 meter, bergantung lokasi. Tanah dan mineral tanah tersebut akan di-dumping untuk kemudian direklamasi atau diperbaiki kembali di lokasi pengambilan setelah batu bara dikeruk.

Secara tegas, narasumber menyampaikan bahwa: "Dalam tataran pelaksanaan, perizinan dan syarat-syarat sudah kami penuhi dengan baik dan tidak ada masalah. Jadi secara hukum kami sudah tepat, tidak ada kesalahan yang kami lakukan, namun pada saat tertentu memang terjadi kebocoran-kebocoran yang pada dasarnya tidak kami sengaja, dan cepat pula kami melakukan perbaikan."

Kedua izin yang dipaparkan di atas tersebut diterbitkan oleh Badan Lingkungan Hidup Bengkulu Tengah dalam rangka meminimalisasi perluasan dampak pencemaran yang meluas ke hilir sungai Bengkulu. 
J.T. Pareke dan David Aprizon Putra: Model Penyelesaian Konflik Kewenangan dalam Hal Timbulnya Dampak Dumping Limbah Batu Bara: Studi Kasus pada Pemerintah Kota Bengkulu dengan Pemerintah Kabupaten Bengkulu Tengah

\section{E. Konsep Ideal Pencegahan Perluasan Dampak Pencemaran yang Seharusnya Dilakukan oleh Pemerintah Provinsi Bengkulu}

Konsep ideal yang ditawarkan berdasarkan fakta hukum dalam Pasal 2 huruf $k$ bahwa perlindungan dan pengelolaan lingkungan hidup dilaksanakan dengan salah satu asasnya yakni partisipatif. Maknanya adalah menekankan setiap anggota masyarakat untuk berperan aktif dalam proses pengambilan keputusan dan pelaksanaan perlindungan dan pengelolaan lingkungan hidup baik secara langsung maupun tidak langsung. Maka pemberian izin oleh pemerintah harus melihat aspek kemanfaatan dari konsekuensi keluarnya izin tersebut dengan melibatkan seluruh elemen masyarakat setempat dan lingkungan sekitarnya.

Ada beberapa hak yang diberikan oleh UUPLH terhadap berbagai pihak yang berkompeten dalam upaya perlindungan dan pengelolaan Hukum Lingkungan hidup, di antaranya yang terdapat pada Pasal 76 ayat (1): "Menteri, gubernur, bupati/walikota menerapkan sanksi administratif kepada penanggung jawab usaha dan/atau kegiatan jika dalam pengawasan ditemukan pelanggaran terhadap izin lingkungan". Amanat UUPLH yang diberikan kepada pemerintah tersebut sangat jelas, di mana diberikan satu tanggung jawab moral kepada pemerintah dalam pelaksanaan perlindungan dan pengelolaan hidup di Indonesia. Ketentuan lebih lanjut diatur pada Pasal yang sama dalam ayat (2), yang berbunyi: "Sanksi administratif terdiri atas: teguran tertulis, paksaan pemerintah, pembekuan izin dan pencabutan izin".

Pada tataran praktik sering terjadi inkonsistensi penegakan hukum, bahkan untuk kondisi di daerah Bengkulu. Pemerintah seharusnya dapat mengambil tindakan terhadap pencemaran yang terjadi di daerah hulu Sungai Bengkulu dengan cepat sebagai bentuk kebijakan untuk mencegah perluasan dampak pencemaran yang akan terjadi. Bahkan pada tataran evaluasi, banyak sekali pelaku usaha yang beroperasi menimbulkan dampak langsung maupun tidak langsung terhadap pencemaran lingkungan hidup. Sebagai contoh, dalam rentang waktu tahun 2008 sampai dengan 2013, perusahaan-perusahaan batu bara yang menggunakan instrumen dumping tersebut tetap beroperasi meskipun tidak adanya perlakuan serius untuk menindak pelanggaran-pelanggaran yang terjadi.

Selain itu, UUPLH juga memberikan hak terhadap pemerintah/pemerintah daerah yang dimuat dalam Pasal 90 ayat (1): "Instansi pemerintah dan pemerintah daerah yang bertanggung jawab di bidang lingkungan hidup berwenang mengajukan gugatan ganti kerugian dan tindakan tertentu terhadap pelaku usaha yang menyebabkan pencemaran dan/atau menyebabkan kerusakan lingkungan hidup yang menyebabkan kerugian lingkungan hidup". Selanjutnya, pada UUPLH juga 
J.T. Pareke dan David Aprizon Putra: Model Penyelesaian Konflik Kewenangan dalam Hal Timbulnya Dampak Dumping Limbah Batu Bara: Studi Kasus pada Pemerintah Kota Bengkulu dengan Pemerintah Kabupaten Bengkulu Tengah

diberikan hak kepada masyarakat yang tertera dalam Pasal 91 ayat (1): “Masyarakat berhak mengajukan gugatan perwakilan kelompok untuk kepentingan dirinya dan/atau untuk kepentingan masyarakat apabila mengalami kerugian akibat pencemaran dan/atau kerusakan lingkungan hidup". Karena keterbatasan akan pengetahuan tentang pengaturan hak tersebut, maka amanat UUPLH yang diberikan tidak dapat dimanfaatkan secara maksimal.

Berbeda dengan organisasi lingkungan hidup, pengaturan hak yang diberikan terdapat pada Pasal 92 ayat (1), yang disebutkan bahwa : Dalam rangka pelaksanaan tanggung jawab perlindungan dan pengelolaan lingkungan hidup, organisasi lingkungan hidup berhak mengajukan gugatan untuk kepentingan pelestarian lingkungan hidup". Sementara yang terjadi di lapangan, organisasi lingkungan hidup yang ada merekam pelanggaran-pelanggaran yang terjadi berikut data-data pendukungnya, tetapi pada akhirnya perlahan-lahan aktivitas perlindungan terhadap lingkungan hidup tersebut hilang dari peredaran.

Berkaca dari fakta hukum yang ada di atas dan fenomena penegakan hukum yang ada, telah terjadi inkonsistensi penegakan hukum lingkungan di Indonesia, khususnya di Provinsi Bengkulu, yang diberikan otoritas dan berkepentingan terhadap perlindungan dan pengelolaan lingkungan hidup. Semangat kebersamaan ketiga komponen tersebut akan menghasilkan suatu konsep baku dan ideal dalam perlindungan dan pengelolaan lingkungan hidup secara terpadu dan berkelanjutan sebagai bentuk pencegahan perluasan dampak pencemaran yang terjadi seperti bagan berikut:

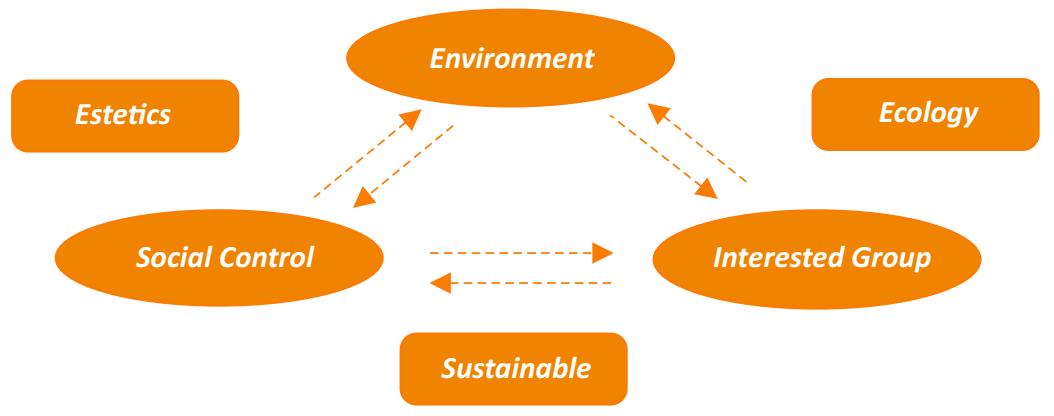

\section{F. Penutup}

Dari penjabaran di atas, maka dapat disimpulkan bahwa ada beberapa dampak yang diakibatkan dari pencemaran limbah batu bara, di antaranya: pertama, dampak terhadap kerusakan ekosistem sungai, dampak terhadap kondisi air (PDAM Kota 
J.T. Pareke dan David Aprizon Putra: Model Penyelesaian Konflik Kewenangan dalam Hal Timbulnya Dampak Dumping Limbah Batu Bara: Studi Kasus pada Pemerintah Kota Bengkulu dengan Pemerintah Kabupaten Bengkulu Tengah

Bengkulu), efek domino yang terjadi di hilir sungai, dan dampak terhadap estetika lingkungan; kedua, tindakan pencegahan yang dilakukan terhadap perluasan dampak pencemaran bagi perusahaan di daerah hulu Sungai Bengkulu masih terbatas pada instrumen perizinan saja, tidak menitikberatkan pada pengawasan yang lebih ketat; ketiga, konsep ideal pencegahan perluasan dampak pencemaran yang seharusnya dilakukan adalah dengan melibatkan berbagai pihak terkait, seperti pemerintah, masyarakat, dan stakeholder yang dimotori oleh pemerintah daerah provinsi, karena konflik kewenangan ini menyangkut dua wilayah administratif yang berbeda. Untuk perbaikan ke depannya, Penulis menyarankan ada perbaikan pada titik tolak inkonsistensi penegakan hukum lingkungan di Indonesia umumnya dan Provinsi Bengkulu khususnya dengan pemahaman akan tanggung jawab seluruh komponen masyarakat yang belum tertata dengan baik dari para pihak yang berkepentingan dalam perlindungan dan pengelolaan lingkungan hidup, terutama pemerintah sebagai motor yang berwenang dalam proses perizinan terhadap perusahaan-perusahan di wilayahnya masing-masing. Kemudian pelaku usaha (interested group), dan kontrol para pihak yang berkepentingan seperti masyarakat, akademisi, praktisi, dan organisasi lingkungan hidup sebagai social control demi tercapainya pencegahan perluasan dampak pencemaran yang terjadi di sekitar hilir Sungai Bengkulu.

\section{Daftar Pustaka}

\section{Buku}

A. Sonny Keraf, Etika Lingkungan, Penerbit Buku Kompas, Jakarta, 2002.

Daud Silalahi, Hukum Lingkungan dalam Sistem Penegakan Hukum Lingkungan Indonesia, Alumni, Bandung, 2001.

Jorgensen, S.E, Halling-Sorensen, S.E, Nielsen, Handbook of Environmental and Ecological Modeling, CRC Press Inc, New York, 1996.

Kodoatie, Robert J. \& Sugiyanto, Banjir: Beberapa Penyebab dan Metode Pengenadaliannya dalam Perspektif Lingkungan, Pustaka Pelajar, Yogyakarta, 2002.

Nandang Sudrajat, Teori dan Praktik Pertambangan Indonesia Menurut Hukum, Pustaka Yustisi, Yogyakarta, 2011.

N.H.T Siahaan, Hukum Lingkungan dan Ekologi Pembangunan, Erlangga, Jakarta, 2010.

Nugroho Iwan, Rochmin Dahuri, Pembangunan Wilayah: Perspektif Ekonomi, Sosial dan Lingkungan, LP3S, Jakarta, 2004. 
J.T. Pareke dan David Aprizon Putra: Model Penyelesaian Konflik Kewenangan dalam Hal Timbulnya Dampak Dumping Limbah Batu Bara: Studi Kasus pada Pemerintah Kota Bengkulu dengan Pemerintah Kabupaten Bengkulu Tengah

Oka Ardiansyah, Rika Mustikasari, Gambaran Umum Permasalahan Pengelolaan Air

DAS Air Bengkulu, Telapak-Yayasan Ulayat, Bengkulu, 2011.

Otto Soemarwoto, Ekologi, Lingkungan Hidup dan Pembangunan, Djambatan, Jakarta, 2004.

Philip Morris, Resolving Business Conflict "Strategi Cerdik Menuju Win-win Solution", Prestasi Pustaka, Jakarta, 2003.

Tresna Wijaya, Pencemaran Lingkungan, Rineka Cipta, Jakarta, 2010.

\section{Dokumen Lain}

Indo Tekhno Plus, "Bengkulu Uji Pencemaran Air Sungai Bengkulu", http://www.indotekhnoplus.com/news/view/140/Bengkulu-Uji-PencemaranAir-Sungai.

J.T. Pareke, "A Study of the Inconsistency of Environment Law Application through the Curriculum of Environment Law Teaching and Learning Approach", Jurnal Ilmiah KUTEI, ISSN 1412-9639, Edisi 22, April 2012. -," Efektivitas Pelaksanaan Instrumen Dumping terhadap Pencemaran Limbah Batu Bara Di Daerah Aliran Sungai (DAS) Sungai Bengkulu berdasarkan Undang-Undang Nomor 32 Tahun 2009 tentang Perlindungan dan Pengelolaan Lingkungan Hidup", Makalah Seminar Nasional Hukum Lingkungan di Universitas Padjadjaran, Selasa 28 Mei 2013.

Kompas, "70 Persen Kerusakan Lingkungan Akibat Operasi Tambang" http://regional.kompas.com/read/2012/09/28/17313375/70.Persen.Kerusaka n.Lingkungan.akibat.Operasi.Tambang.

YUB Internal Report (Unpublished), Laporan Multipihak Berasan Air Bengkulu dalam Memperingati Hari Air Se-Dunia di Hotel Nala Sea Side, Yayasan Ulayat, Bengkulu, 2011.

\section{Dokumen Hukum}

Undang-Undang Dasar Negara Republik Indonesia Tahun 1945.

Undang-Undang Nomor 4 Tahun 2009 tentang Pertambangan Mineral dan Batu Bara. Undang-Undang Nomor 32 Tahun 2009 tentang Pengelolaan dan Perlindungan Hidup. 